\title{
The Role of s-TREM in Distinction of Congestive Heart Failure and Pneumonia in Patients With Dyspnea in the Emergency Department
}

\author{
Nefes Darlı̆ı ile Acil Servise Bașvuran Hastalarda s-TREM'in Konjestif Kalp Yetmezliği ve \\ Pnömoni Ayrımındaki Rolü
}

\author{
Ceren Sen Tanrikulu', Hilal Hocagil'2, Emine Gencer ${ }^{3}$, Ercan Gencer ${ }^{4}$, A. Cuneyt Hocagil ${ }^{2}$ \\ ${ }^{1}$ Emergency Medicine Clinic, Konya Training and Research Hospital, Konya; ${ }^{2}$ Department of Emergency Medicine, Bulent Ecevit \\ University Faculty of Medicine, ${ }^{3}$ Chest Diseases Department, Zonguldak Ataturk State Hospital; ${ }^{4}$ Department of Physiology, Bulent \\ Ecevit University Faculty of Medicine, Zonguldak, Turkey
}

\begin{abstract}
Aim: Congestive heart failure (CHF) and pneumonia are the most important causes of potentially death due to dyspnea in patients presenting at the Emergency Department. Early diagnosis and suitable treatment are lifesaving in cases of both CHF and pneumonia. The aim of this study was to investigate the diagnostic ability of the soluble triggering receptor expressed on myeloid cells-1 (sTREM-1) which is an inflammatory biomarker in the differential diagnosis of pneumonia from $\mathrm{CHF}$.
\end{abstract}

Material and Method: This prospective study was conducted from 1 Jun 2014 to 30 May 2015 in the emergency medicine departments of urban and university hospitals. Patients presenting with dyspnea were evaluated and divided into two groups according to the diagnoses made according to international guidlines; CHF group and pneumonia group. The groups were compared in respect of clinical and demographic characteristics and STREM-1 levels.

Results: 15 patients were evaluated in each group. Pulse rate was higher in the CHF group $(p<0.001)$, and respiration rate and temperature values were higher in the pneumonia group $(p=0.002$, $p=0.008$ ). On the chest radiographs, significant infiltration was observed in the pneumonia group, and cardiomegaly in the CHF group $(p<0.001)$. The sTREM-1 levels were higher in the pneumonia group than the CHF group, and the difference was statistically significant $(p=0.044)$.

Conclusion: We think that STEM can be used in the differential diagnosis of dyspnea in the emergency departments, but this should be supported by more comprehensive studies.

Key words: chronic heart failure; pneumonia; sepsis; sTREM-1

\section{ÖZET}

Amaç: Konjestif kalp yetmezliği (KKY) ve pnömoni acil servise nefes darlığı ile bașvuran hastalarda en önemli potansiyel ölüm nedenleridir. Hem KKY hem de pnömonide erken tanı ve uygun müdahale hayat kurtarıcıdır. Bu çalıșmanın amacı, pnömoninin CHF'den ayırıcı tanısında inflamatuar bir biyobelirteç olan miyeloid hücreler-1 üzerinde eksprese olan çözünür tetikleyici reseptörün (sTREM-1) tanısal yeteneğini araștırmaktır.

Materyal ve Metot: Bu prospektif çalıșma, 1 Haziran 2014 - 30 Mayıs 2015 tarihleri arasında devlet hastanesi ve üniversite hastanelerinin acil tıp bölümlerinde gerçekleștirildi. Dispne ile bașvuran hastalar uluslararası kılavuzlara göre yapılan tanılara göre değerlendirildi ve iki gruba ayrıld; CHF grubu ve pnömoni grubu. Gruplar klinik ve demografik özellikler ve sTREM-1 düzeyleri açısından karșılaștııldı.

Bulgular: Her grupta 15 hasta değerlendirildi. KKY grubunda nabız hızı daha yüksek iken ( $p<0,001)$, pnömoni grubunda solunum hızı ve sıcaklık değerleri daha yüksekti ( $p=0,002, p=0,008)$. Akciğer grafilerinde pnömoni grubunda anlamlı infiltrasyon, $K K Y$ grubunda kardiyomegali gözlendi $(p<0,001)$. STREM-1 düzeyleri, pnömoni grubunda, CHF grubundan daha yüksekti ve aradaki fark istatistiksel olarak anlamlıydı $(p=0,044)$.

Sonuç: Biz STEM'in acil serviste dispnenin ayırıcı tanısında kuulanılabileceğini, ancak daha kapsamlı çalıșmalarla bunun desteklenmesi gerektiğini düșünüyoruz.

Anahtar kelimeler: kronik kalp yetmezliği; pnömoni; sepsis; sTREM-1

İetișim/Contact: Ceren Sen Tanrlkulu, Emergency Medicine Clinic, Konya Training and Research Hospital, Konya, Turkey • Tel: 05058871387 • E-mail: cerensen81@hotmail.com • Geliș/Received:08.02.2020• Kabul/Accepted:08.05.2020

ORCID: Ceren Sen Tanrkulu, 0000-0001-8166-3823 • Hilal Hocagil, 0000-0001-7314-752X • Emine Gencer, 0000-0002-5718-626X • Ercan Gencer, 0000-0002-9004-0123 • A. Cuneyt Hocagil, 0000-0002-1675-9754 


\section{Introduction}

Dyspnea develops for many reasons, including respiratory, cardiovascular system and central nervous system pathologies and metabolic disorders, and is an important part of Emergency Room admissions and referrals from the Emergency Dept. The majority of these causes present challenges in the differential diagnosis, and a delay in the diagnosis of dyspnea is associated with high rates of morbidity and mortality ${ }^{1-3}$.

Congestive heart failure (CHF) and pneumonia are among the most important and potentially fatal causes of dyspnea in patients presenting at the Emergency Department. Another important cause of dyspnea is pneumonia, which although relatively uncommon in the community, is an acute infection characterized by consolidation areas in the lung parenchyma caused by bacteria, viruses, fungi and other microorganisms ${ }^{4}$. In pneumonia, the diagnostic process begins with clinical suspicion arising from the patient complaints such as fever, cough and sputum. It is routine for a chest X-ray to be taken of these patients in the Emergency Dept to support the diagnosis. White blood cell (WBC), gram stain of sputum, and biomarkers related to the inflammation are also examined and if necessary thorax tomography is taken 5 .

$\mathrm{CHF}$ is a progressive disorder of structural and functional heart disorders which leads to the provision of insufficient oxygen to meet the metabolic needs of the tissues despite the normal filling pressure ${ }^{6}$. For the diagnosis of patients with heart failure who are admitted to the Emergency Department with signs and symptoms similar to pneumonia, chest radiography, transthoracic echocardiography and some biomarkers are used. However, echocardiography and tomography are not available in all centres, and require experienced professionals for use and review ${ }^{7}$.

Early diagnosis and suitable treatment are lifesaving in both CHF and pneumonia. However, there may be difficulties in making the differential diagnosis as patients of both groups present at the Emergency Dept with similar clinical symptoms. Therefore, there is a need for a diagnositc test which is reliable, easily accessible, provides quick results and is low $\operatorname{cost}^{2,3}$. Inflammatory biomarkers such as elevated white blood cell (WBC), procalcitonin (PCT) and C-reactive protein (CRP) are used for the differential diagnosis of pneumonia. However, these markers may increase in many non-inflammatory conditions causing systemic inflammatory response syndrome $e^{8,9}$.

Soluble triggering receptor expressed on myeloid cells-1 (sTREM-1), is a member of the immunoglobulin superfamily and a surface receptor of mature polymorphonuclear leukocytes expressed in septic-septic inflammatory processes. Serum and infected materials such as cerebrospinal fluid and pleural fluid are used for measurement. The use of sTREM-1 as a marker in acute infections has been shown in several studies ${ }^{10}$.

In this preliminary study, unstable patient presenting with dyspnea, we investigated the diagnostic value of $s$-trem to differentiate whether the etiology is sepsisinduced severe pneumonia or congestive heart failure.

\section{Material and Method}

\section{Study Design}

This prospective study was conducted from 1 Jun 2014 to 30 May 2015 in the Emergency Medicine Departments of urban and university hospitals. . Approval for the study was granted by the Regional Ethics Review Committee. Informed consent was obtained from all patients. The pre-study power analysis showed that the chosen sample size afforded a power of 0.9 for achievement of a $95 \%$ confidence interval.

All patients presenting with dyspnea were evaluated. During the initial admission to the Emergency Room, routine medical histories were taken of all patients admitted with dyspnea and physical examinations were applied. Blood pressure, shock index (the ratio of heart rate to systolic blood pressure), heart and respiratory rates, and blood gas values were recorded. Electrocardiography (ECG) and chest x-rays were taken. In addition, echocardiography was used for diagnosis of CHF. Blood samples were then obtained from patients for laboratory analysis. The study included patients aged $18-90$ years, diagnosed with pneumonia or congestive heart failure according to the diagnostic criteria. Patients were excluded if any of the following criteria were present; pulmonary disease without pneumonia such as chronic obstructive pulmonary disease, asthma, pulmonary fibrosis, pulmonary thromboembolism, and tuberculosis, and in the congestive heart failure patients, acute coronary syndrome, dyspnea associated with trauma or cardiac tamponade, end-stage renal disease, malignancies, systemic or local infections other than pneumonia, and pregnant women. 
Patient Groups and Definitions

A total of 53 patients were enrolled in the study, divided into three groups of CHF, pneumonia, and control group.

1. CHF Group $(n=15):$ According to the international guidelines (American College of Cardiology/American Heart Association and the European Society of Cardiology ${ }^{10,11}$, two criteria are required for the diagnosis of CHF: (1) symptoms of heart failure at rest or during exercise, (2) objective evidence of cardiac dysfunction (at rest). Therefore, in patients with clinically suspected $\mathrm{CHF}$, the diagnosis of CHF was based on typical symptoms and clinical findings supported by appropriate investigations such as ECG, chest X-ray, and echocardiography.

2. Pneumonia Group $(n=15)$ : The diagnosis of pneumonia was based on clinical (body temperature $>38^{\circ} \mathrm{C}$ or $<36^{\circ} \mathrm{C}$, heart rate $>90 \mathrm{rpm}$, respiratory rate $>20 \mathrm{bpm}, \mathrm{PaC} 02<32 \mathrm{mmHg}$, white blood cell $(\mathrm{WBC})>12000$ or $<4000$, presence of cough, pleuritic chest pain and dyspnea) and radiological evaluation (presence of pulmonary parenchymal infiltration at the chest radiograph). In addition, thorax tomography was taken for the diagnosis of patients with ongoing suspected pneumonia.

3. Control group $(n=15)$ was formed from healthy volunteers to compare the accuracy rates of s-trem only. No demographic or laboratory parameters were evaluated in these patients except s-trem.

\section{Complete Blood Count (CBC) and Biochemical Analysis}

All biochemical tests and CBCs (on venous blood) were automated. Laboratory data obtained from two centers were similar to the recognized international norms. The normal values of all parameters were the reference values accepted by hematology laboratories nationwide.

\section{Soluble TREM-1 Analysis}

Blood samples were collected into biochemistry tubes, centrifuged and the serum samples were then stored at $-80^{\circ} \mathrm{C}$. The sTREM- 1 analysis was measured using ELISA commercial immunoassay kits on the serum samples.

\section{Statistical Analysis}

All statistical analyses were performed using SPSS version 19.0 software (SPSS Inc., Chicago, IL, USA). The data distribution was evaluated using the KolmogorovSmirnov test. Continuous variables were expressed as mean \pm standard derivation (SD), and categorical variables as number ( $\mathrm{n}$ ) and percentage (\%). The significance of each difference between continuous variables was examined using the Independent Samples t-test or the Mann-Whitney U-test. The significance of each difference between the categorical variables was compared using the Pearson's Chi-squared test. Receiver Operating Characteristic (ROC) curve analysis was used to define the optimal cut-offs of Presepsin. Youden's index was used to optimize the accuracy of all calculations. A value of $\mathrm{p}<0.05$ was accepted as statistically significant.

\section{Results}

A total of 15 pneumonia, $15 \mathrm{CHF}$, and 15 control patients were evaluated. The distribution of demographic and clinical data between the groups is summarized in Table 1. The mean patient age was higher in the CHF group $(\mathrm{p}<0.001)$. No statistically significant difference was determined between the groups in terms of demographic features including gender and smoking. Pulse rate was higher in the CHF group $(p<0.001)$, whereas respiration rate and temperature were higher in the pneumonia group $(\mathrm{p}=0.002, \mathrm{p}=0.008)$. There was no difference according to the co-morbid disease including hypertension (HT), diabetes mellitus (DM), and chronic obstructive pulmonary disease (COPD). In terms of patient complaints on admission, pretibial edema was higher in the CHF group $(p=0.042)$, and cough and sputum were higher in the pneumonia group $(p<0.001$ and $p=0.042)$. In terms of hospitalization, in the pneumonia group, 13 patients were disharged, 1 patients were hospitalized in the clinic, and 1 patient was transferred to the intensive care unit. In the CHF group, these rates were 1,2, and 11 patients, respectively and 1 patient exitus.

The distribution of radiological and cardiological signs between the groups is shown in Table 2. According to the assessment made of the chest radiographs, there was significant infiltration in the pneumonia group and cardiomegaly in the CHF group $(p=0.003$ and $p<0.001$, respectively). There was no statistically significant difference between the groups in respect of pleural effusion and increased bronchoalveolar 
Table 1. Distribution of demographic and clinical data between groups

\begin{tabular}{|c|c|c|c|c|}
\hline & & $\begin{array}{c}\text { Pneumonia } \\
(n=15)\end{array}$ & CHF $(n=15)$ & $\mathrm{p}$ \\
\hline \multicolumn{2}{|c|}{ Age (year) } & $49.26 \pm 19.42$ & $73.80 \pm 12.41$ & $<0.001$ \\
\hline \multicolumn{2}{|c|}{ Gender (M/F) } & $8 / 7$ & $6 / 9$ & 0.129 \\
\hline \multicolumn{5}{|c|}{ Co-morbid diseases } \\
\hline & COPD & $5(33 \%)$ & $5(33 \%)$ & 1.000 \\
\hline & Hypertension & $3(20 \%)$ & $8(53 \%)$ & 0.128 \\
\hline & Diabetes mellitus & $1(7 \%)$ & $3(20 \%)$ & 0.598 \\
\hline & CAD & $0(0 \%)$ & $6(40 \%)$ & 0.017 \\
\hline \multicolumn{5}{|c|}{ Complaints } \\
\hline & Dyspnea & $6(40 \%)$ & $14(\% 93)$ & 0.005 \\
\hline & PTE & $0(0 \%)$ & $5(33 \%)$ & 0.042 \\
\hline & Angina & $2(13 \%)$ & $3(20 \%)$ & 1.000 \\
\hline & Cough & $12(80 \%)$ & $0(0 \%)$ & $<0.001$ \\
\hline & Sputum & $3(33 \%)$ & $0(0 \%)$ & 0.042 \\
\hline Smoking & $10(67 \%)$ & $6(40 \%)$ & 0.272 & \\
\hline \multicolumn{5}{|c|}{ Vital signs } \\
\hline & $\mathrm{TA}(\mathrm{mmHg})$ & $119.89 \pm 17.15$ & $126.70 \pm 28.95$ & 0.389 \\
\hline & Pulse (rpm) & $84.73 \pm 15.34$ & $114.27 \pm 18.91$ & $<0.001$ \\
\hline & Respiratory rate (bpm) & $27.53 \pm 5.42$ & $20.26 \pm 6.26$ & 0.002 \\
\hline & Temperature $\left({ }^{\circ} \mathrm{C}\right)$ & $37.28 \pm 0.82$ & $36.47 \pm 0.88$ & 0.008 \\
\hline & $\mathrm{O}_{2}$ saturation $(\%)$ & $93.67 \pm 5.28$ & $91.00 \pm 6.77$ & 0.285 \\
\hline \multicolumn{5}{|c|}{ Outcomes } \\
\hline & Disharged & $13(87 \%)$ & $1(7 \%)$ & $<0.001$ \\
\hline & Hospitalization (Clinic) & $1(7 \%)$ & $2(13 \%)$ & 0.340 \\
\hline & Hospitalization (ICU) & $1(7 \%)$ & $11(73 \%)$ & $<0.001$ \\
\hline & Exitus & $0(0 \%)$ & $1(7 \%$ & 0.433 \\
\hline
\end{tabular}

branching. Computed tomographic angiography was applied to all patients to clarify the differential diagnosis. However, no significant difference was determined between the groups, so it did not contribute to the diagnosis. The ECG rhythms of the pneumonia group were usually normal sinus rhythm, but in the CHF group, left bundle branch block and sinus tachycardia were higher $(\mathrm{p}=0.017)$.

The distribution of laboratory data between groups is summarized in Table 3. Urea, creatinin, and troponin levels were higher in the CHF group $(p<0.026$, $p=0.005, p=0.012$, and $p=0.026$, respectively). there is no difference between the groups in terms of other laboratory parameters.

ThesTREM-1 levelsweredetermined as $488.21 \pm 153.80$ in the pneumonia group, $370.08 \pm 99.23$ in the $\mathrm{CHF}$
Table 2. Distribution of radiological and cardiological signs between groups

\begin{tabular}{|c|c|c|c|}
\hline & Pneumonia $(n=15)$ & CHF $(n=15)$ & $\mathrm{p}$ \\
\hline \multicolumn{4}{|l|}{ Thorax X-ray } \\
\hline Infiltration & $13(87 \%)$ & $4(27 \%)$ & 0.003 \\
\hline Pleural effusion & $4(27 \%)$ & $4(27 \%)$ & 1.000 \\
\hline Cardiomegaly & $1(7 \%)$ & $11(73 \%)$ & $<0.001$ \\
\hline $\begin{array}{l}\text { Bronchoalveolar } \\
\text { branching }\end{array}$ & $2(13 \%)$ & $6(40 \%)$ & 0.215 \\
\hline \multicolumn{4}{|l|}{ Electrocardiographic findings } \\
\hline $\begin{array}{l}\text { Normal } \\
\text { sinus rhythm }\end{array}$ & $11(73 \%)$ & $0(0 \%)$ & $<0.001$ \\
\hline $\begin{array}{l}\text { Left bundle } \\
\text { branch block }\end{array}$ & $0(0 \%)$ & $6(40 \%)$ & 0.017 \\
\hline $\begin{array}{l}\text { Reft bundle } \\
\text { branch block }\end{array}$ & $1(7 \%)$ & $1(7 \%)$ & 1.000 \\
\hline Atrial fibrillation & $1(7 \%)$ & $3(20 \%)$ & 0.598 \\
\hline Extrasystoles & $0(0 \%)$ & $3(20 \%)$ & 0.224 \\
\hline \multicolumn{4}{|l|}{ Echocardiographic findings } \\
\hline Ejection fraxion & $59.00 \pm 6.37$ & $32.53 \pm 17.25$ & 0.002 \\
\hline $\begin{array}{l}\text { Systolic } \\
\text { dysfunction }\end{array}$ & $1(7 \%)$ & $12(80 \%)$ & 0.071 \\
\hline $\begin{array}{l}\text { Diastolic } \\
\text { dysfunction }\end{array}$ & $1(7 \%)$ & $6(40 \%)$ & 1.000 \\
\hline $\begin{array}{l}\text { Pulmonary } \\
\text { artery pressure }\end{array}$ & $36.67 \pm 7.64$ & $49.00 \pm 12.65$ & 0.076 \\
\hline $\begin{array}{l}\text { Valvular } \\
\text { insufficiency }\end{array}$ & $1(7 \%)$ & $12(80 \%)$ & 0.071 \\
\hline \multicolumn{4}{|l|}{ CT angiographic findings } \\
\hline Pneumonia & $4(27 \%)$ & $1(7 \%)$ & 0.143 \\
\hline Pleural effusion & $2(13 \%)$ & $1(7 \%)$ & 1.000 \\
\hline Cardiomegaly & $2(13 \%)$ & $3(20 \%)$ & 1.000 \\
\hline
\end{tabular}

group, and $96.54 \pm 47.71$ in the control group. The difference between the control group and the other groups was statistically significant $(\mathrm{p}<0.001)$. The sTREM-1 levels were higher in the pneumonia group than the CHF group, and the difference was statistically significant $(\mathrm{p}=0.044)$.

The sensitivities and specificities of the sTREM-1 levels used to differentiate the pneumonia and CHF patients and the ROC data on the sTREM-1 levels are shown in Figure 1. The sensitivity, specificity, PPV, and NPV of the sTREM-1 levels were found to be $93.33 \%$, $53.33 \%, 66.70 \%$, and $88.90 \%$. ROC analysis showed that the cut-off value for the sTREM-1 levels affording the best sensitivity and specificity was $396.74 \mathrm{pg} / \mathrm{mL}$ (68-98\%). The areas under the curves (AUC) for the sTREM-1 levels was 0.760 . 
Table 3. Distribution of laboratory data between groups

\begin{tabular}{lccc}
\hline & Pneumonia $(\mathrm{n}=15)$ & $\mathrm{CHF}(\mathrm{n}=15)$ & $\mathrm{p}$ \\
\hline WBC & $14.54 \pm 14.86$ & $13.93 \pm 7.59$ & 0.870 \\
Hemoglobin & $13.21 \pm 1.62$ & $12.58 \pm 1.38$ & 0.148 \\
Platelet count & $270.40 \pm 88.15$ & $244.20 \pm 63.42$ & 0.713 \\
Urea & $32.01 \pm 14.38$ & $89.86 \pm 9.50$ & $<0.001$ \\
Creatinin & $0.82 \pm 0.19$ & $1.55 \pm 1.00$ & $<0.001$ \\
AST & $30.73 \pm 20.71$ & $97.13 \pm 18.27$ & 0.050 \\
ALT & $29.44 \pm 24.09$ & $13.26 \pm 37.07$ & 0.202 \\
pH & $7.42 \pm 0.07$ & $7.38 \pm 0.10$ & 0.611 \\
p0 & $79.33 \pm 17.55$ & $60.03 \pm 14.90$ & 0.146 \\
CO ${ }_{2}$ & $38.66 \pm 11.54$ & $54.44 \pm 53.01$ & 0.800 \\
O $_{2}$ saturation $(\%)$ & $95.66 \pm 0.57$ & $85.99 \pm 8.25$ & 0.014 \\
Lactate & $1.03 \pm 0.55$ & $2.44 \pm 1.70$ & 0.057 \\
C0 & $1.50 \pm 1.00$ & $1.02 \pm 0.67$ & 0.439 \\
Troponine & $0.01 \pm 0.00$ & $0.18 \pm 0.29$ & 0.018 \\
sTREM-1 & $488.21 \pm 153.80$ & $370.08 \pm 99.23$ & 0.044 \\
\hline
\end{tabular}

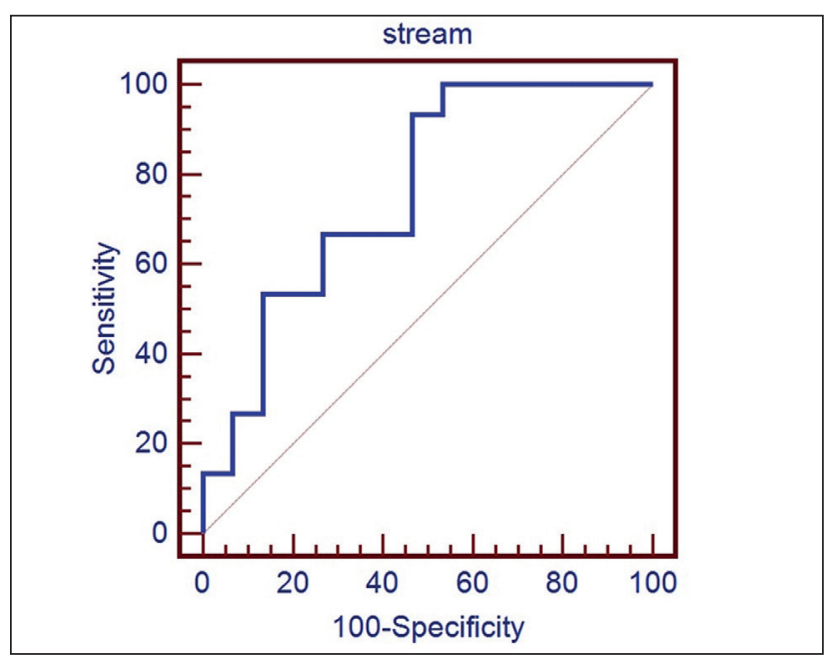

Figure 1. ROC data on STREM-1 levels used to differentiate pneumonia and CHF patients.

\section{Discussion}

The results of this study demonstrated that sTREM-1, sampled in blood, can accurately discriminate pneumonia from $\mathrm{CHF}$.

Dyspnea accounts for about $2.7 \%$ of emergency clinic admissions and 15-25\% of all hospital admissions. On first admission, the differential diagnosis of dyspnea with cardiac or pulmonary causes can be quite difficult. Physical examination, laboratory tests, ECG, and chest $\mathrm{X}$-rays are not always sufficiently accurate to make the correct diagnosis ${ }^{11-13}$. The disadvantage of echocardiography used in differential diagnosis is the difficulty of accessibility, non-availability in emergency clinics, and the need for experienced staff ${ }^{14,15}$. Likewise, the use of thoracic tomography is limited for similar reasons and high cost. As routine laboratory tests are non-specific, they may not always give accurate results.

Fast and accurate diagnosis of patients with dyspnea admitted to the emergency clinic and suitable and quick treatment are very important to reduce patient mortality and morbidity rates ${ }^{12,15}$. Namely, CHF is a progressive disorder and can be fatal if untreated ${ }^{16}$. In a study by Hunt ${ }^{17}$, CHF was found to be the major cause of hospital admissions. Epidemiological studies have also shown that this situation is likely to become worse in the future, and will increase mortality rates. However, accurate, early, and rapid diagnosis and treatment can be life-saving as CHF patients with left ventricular dysfunction recover rapidly with medical treatment ${ }^{15,18}$. Levine et al. ${ }^{19}$ determined that patients with $\mathrm{CHF}$ had elevated circulating levels of tumor necrosis factor (TNF). In another study, BNP was able to distinguish CHF from pulmonary and other clinical presentations with high specificity, sensitivity and accuracy $^{15}$. Therefore, BNP has been found to be useful in the evaluation of patients with dyspnea or with LV dysfunction ${ }^{20}$.

Pneumonia is the still primary cause of death due to infection in western countries, despite advances made in antibiotic therapy, and improvements to diagnostic tools and intensive care $(5.7 \%-14 \%)^{21}$. Early diagnosis is known to be a key factor in reducing morbidity and mortality due to pneumonia ${ }^{22}$. There have been studies of the early diagnosis of pneumonia in addition to CHF. In a study by Schuetz et al, the prognostic capacity of 5 rohormones including proADM, endothelin-1, atrial-natriuretic peptide, copeptin, and procalcitonin was investigated in patients with lower respiratory tract infections and community-acquired pneumonia $(\mathrm{CAP})^{23}$. In another CAP-related study, Krüger et al. ${ }^{24}$, investigated the predictive value of many markers, and found that proADM (proadrenomedullin) was the best predictive biomarker.

Many of these studies were conducted inspired by the thesis that pneumonia is a septic disease. More than a hundred biomarkers have been studied in septic patients $^{25}$. The most commonly used of these new diagnostic and prognostic biomarkers are sTREM-1, soluble urokinase-type Plasminogen receptor (suPAR), ProADM, and Presepsin ${ }^{26}$. 
Soluble TREM-1, a member of the immunoglobulin superfamily, triggers an inflammatory response by releasing cytokines, increasing cell surface receptors, and activating neutrophil degranulation and oxidative stress. sTREM-1 has been used as a diagnostic biomarker in several studies ${ }^{27}$. Zhang J et al..$^{28}$, found that sTREM-1 levels accurately reflect the severity of sepsisand are a sensitive prognostic biomarker. Ramirez et al. $^{29}$ used sTREM-1 to differentiate pneumonia and intra-abdominal infections, an it was found that sTREM-1 can be used in the separation of specific infections. Already, the most important hypothesis in this study was the diagnostic value of s-trem in differentiating the group of patients with severe pneumonia with sepsis from the other group. In our study, we found that the sTREM-1 levels were higher in the pneumonia group than the CHF group, and the difference was statistically significant $(\mathrm{p}=0.044)$.

The clinical and demographic parameters which were used to discriminate pneumonia from CHF are usually disease-specific findings. Namely, rhythm disorders and echocardiographic findings were more pronounced in heart failure, while thorax X-ray and CT angiographic findings were evident in the pneumonia group. The laboratory parameters were similar to these. The sTREM-1 levels were lower in the CHF group than the control and pneumonia groups, and were consistent with the findings in literature in correlation with sepsis. According to the results of the current study, sTREM assayed quickly and easily can be considered beneficial for use in Emergency Depts in the differential diagnosis of dyspnea. However, there is a need for further high volume studies to support these findings.

\section{Limitations}

This study has some limitations. Firstly, the number of cases in the study groups is very low, so it can be considered as a preliminary study. Secondly, it is not possible to create isolated CHF and isolated pneumonia cases, since the majority of patients have comorbid causes.

\section{Conflicting Interests}

The authors declare that they have no conflicting interest.

\section{Financial Disclosure}

There are no financial supports.

\section{Ethical Approval}

Ethical committee approval of this study has been obtained from the Ethics Committee of Bülent Ecevit University (Date: 07.07.2015, Number: 2015/06).

\section{References}

1. Stokes NR, Dietz BW, Liang JJ. Cardiopulmonary laboratory biomarkers in the evaluation of acute dyspnea. Open Access Emerg Med 2016;8:35-45.

2. Michtalik HJ, Yeh HC, Campbell CY, Haq N, Park H, Clarke $\mathrm{W}$, et al. Acute changes in $\mathrm{N}$-terminal pro-B-type natriuretic peptide during hospitalization and risk of readmission and mortality in patients with heart failure. Am J Cardiol 2011;107:1191-5.

3. Ferrandis MJ, Ryden I, Lindahl TL, Larsson A. Ruling out cardiac failure: cost-benefit analysis of a sequential testing strategy with NT-proBNP before echocardiography. Ups J Med Sci 2013;118:75-9.

4. Januzzi JL Jr, Chen-Tournoux AA, Moe G. Amino-terminal pro- B-type natriuretic peptide testing for the diagnosis or exclusion of heart failure in patients with acute symptoms. Am J Cardiol 2008;101:29-38.

5. Rosón B, Carratalà J, Dorca J, Casanova A, Manresa F, Gudiol F. Etiology, reasons for hospitalization, risk classes, and outcomes of community-acquired pneumonia in patients hospitalized on the basis of conventional admission criteria. Clin Infect Dis 2001;33:158-65.

6. Schuetz P, Briel M, Mueller B. Clinical outcomes associated with procalcitonin algorithms to guide antibiotic therapy in respiratory tract infections. JAMA 2013;309:717-8.

7. Schuetz P, Briel M, Christ-Crain M, Stolz D, Bouadma L, Wolff $\mathrm{M}$, et al. Procalcitonin to guide initiation and duration of antibiotic treatment in acute respiratory infections: an individual patient data meta-analysis. Clin Infect Dis 2012;55:651-62.

8. Dickstein K, Cohen-Solal A, Filippatos G, McMurray JJ, Ponikowski P, Poole-Wilson PA, et al. ESC guidelines for the diagnosis and treatment of acute and chronic heart failure 2008: the Task Force for the diagnosis and treatment of acute and chronic heart failure 2008 of the European Society of Cardiology. Developed in collaboration with the Heart Failure Association of the ESC (HFA) and endorsed by the European Society of Intensive Care Medicine (ESICM). Eur J Heart Fail 2008;10:933-89.

9. Aikawa N, Fujishima S, Endo S, Sekine I, Kogawa K, Yamamoto $\mathrm{Y}$, et al. Multicenter prospective study of procalcitonin as an indicator of sepsis. J Infect Chemother 2005;11:152e9.

10. Endo S, Aikawa N, Fujishima S, Sekine I, Kogawa K, Yamamoto $\mathrm{Y}$, et al. Usefulness of procalcitonin serum level for the discrimination of severe sepsis from sepsis: a multicenter prospective study. J Infect Chemother 2008;14:244-9.

11. Endo S, Sato N, Suzuki Y, Kojika M, Takahashi G, Yamada Y, et al. Significance of measuring procalcitonin values for diagnosis of sepsis. J Jpn Soc Surg Infect 2007;4:112-20.

12. Mulrow C, Lucey C, Farnett L. Discriminating causes of dyspnea through the clinical examination. J Gen Intern Med 1993;8:383-92.

13. Yurchyak PM. Cardiac problems in the pulmonary patient. Fishman AP, ed. Pulmonary Diseases and Disorders, 2nd ed. New York, NY: McGraw-Hill; 1988. 
14. Deveraux RB, Liebson PR, Horan MJ. Recommendations concerning use of echocardiography in hypertension and general population research. Hypertension 1987;9:97-104.

15. Morrison LK, Harrison A, Krishnaswamy P, Kazanegra R, Clopton P, Maisel A. Utility of a rapid B-natriuretic peptide assay in differentiating congestive heart failure from lung disease in patients presenting with dyspnea. J Am Coll Cardiol 2002;39:202-9.

16. Hartupee J, Mann DL. Positioning of inflammatory biomarkers in the heart failure landscape. J Cardiovasc Transl Res 2013;6:485-92.

17. Hunt SA, Abraham WT, Chin MH, Feldman AM, Francis GS, Ganiats TG, et al. ACC/AHA 2005 Guideline Update for the Diagnosis and Management of Chronic Heart Failure in the Adult: a report of the American College of Cardiology/ American Heart Association Task Force on Practice Guidelines (Writing Committee to Update the 2001 Guidelines for the Evaluation and Management of Heart Failure): developed in collaboration with the American College of Chest Physicians and the International Society for Heart and Lung Transplantation: endorsed by the Heart Rhythm Society. Circulation. 2005;112:154-235.

18. Wuerz RC, Meador SA. Effects of prehospital medications on mortality and length of stay in CHF. Ann Emerg Med 1992;21:669-74.

19. Levine B, Kalman J, Mayer L, Fillit HM, Packer M. Elevated circulating levels of tumor necrosis factor in severe chronic heart failure. The New England Journal of Medicine 1990;323:236-41.

20. Dao Q, Krishnaswamy P, Kazanegra R, Harrison A, Amirnovin $\mathrm{R}$, Lenert L, et al. Utility of b-type natriuretic peptide (BNP) in the diagnosis of CHF in an urgent care setting. J Am Coll Cardiol 2001;37:379-85.

21. Chalmers JD, Singanayagam A, Akram AR, Mandal P, Short PM, Choudhury G, et al. Severity assessment tools for predicting mortality in hospitalised patients with communityacquired pneumonia. Systematic review and meta-analysis. Thorax 2010;65:878-83.
22. Richards G, Levy H, Laterre PF, Feldman C, Woodward B, Bates BM, et al. CURB-65, PSI, and APACHE II to assess mortality risk in patients with severe sepsis and community acquired pneumonia in PROWESS. J Intensive Care Med 2011;26:34-40.

23. Schuetz P, Wolbers M, Christ-Crain M, Thomann R, Falconnier C, Widmer I, et al. Prohormones for prediction of adverse medical outcome in community-acquired pneumonia and lower respiratory tract infections. Crit Care 2010;14:R106.

24. Krüger S, Ewig S, Giersdorf S, Hartmann O, Suttorp N, Welte T. Cardiovascular and inflammatory biomarkers to predict shortand longterm survival in community-acquired pneumonia: Results from the German Competence Network, CAPNETZ. Am J Respir Crit Care Med 2010;182:1426-34.

25. Pierrakos C, Vincent JL: Sepsis biomarkers: a review. Crit Care 2010;14:R15.

26. Bouchon A, Dietrich J, Colonna M. Cutting edge: inflammatory responses can be triggered by TREM-1, a novel receptor expressed on neutrophils and mono-cytes. J Immunol 2000;164:4991-5.

27. Gibot S, Cravoisy A, Levy B, Bene MC, Faure G, Bollaert PE. Soluble triggering receptor expressed on myeloid cells and the diagnosis of pneumonia. N Engl J Med 2004;350:451-8.

28. Zhang J, She D, Feng D, Jia Y, Xie L. Dynamic changes of serum soluble triggering receptor expressed on myeloid cells-1 (sTREM-1) reflect sepsis severity and can predict prognosis: a prospective study. BMC Infect Dis 2011;11:53.

29. Ramirez P, Kot P, Marti V, Gomez MD, Martinez R, Saiz V, et al. Diagnostic implications of soluble triggering receptor expressed on myeloid cells- 1 in patients with acute respiratory distress syndrome and abdominal diseases: a preliminary observational study. Crit Care 2011;15:R50. 